\title{
Assessment of research productivity of Arab countries in the field of infectious diseases using Web of Science database
}

Waleed M Sweileh ${ }^{1 *}$, Samah W Al-Jabi ${ }^{2}$, Alaeddin Abuzanat ${ }^{3}$, Ansam F Sawalha ${ }^{1}$, Adham S AbuTaha', Mustafa A Ghanim ${ }^{4}$ and Sa'ed H Zyoud ${ }^{2}$

\begin{abstract}
Background: To meet the future challenges of infectious diseases and limit the spread of multidrug resistant microorganisms, a better understanding of published studies in the field of infectious diseases is needed. The objective of this study was to analyze the quantity and quality of research activity in the field of infectious diseases in Arab countries and compare it with that in non-Arab countries.

Methods: Documents published in Arab countries within the research category of "infectious diseases" were extracted and analyzed using the Web of Science database. The data analyzed represent research productivity during the time interval between $1900-2012$.
\end{abstract}

Results: Worldwide, the total number of documents published in the field of infectious diseases up to 2012 was 227,188. A total of 2,408 documents in the field of infectious diseases were published in Arab countries, which represents $1.06 \%$ of worldwide research output. Research output from Arab countries in the field of infectious diseases was low for decades. However, approximately a five-fold increase was observed in the past decade. Arab countries ranked $56^{\text {th }}$ to $218^{\text {th }}$ on the standard competition ranking (SCR) in worldwide publications in the field of infectious diseases. Egypt, with a total publication of 464 (19.27\%) documents ranked first among Arab countries, while Kuwait University was the most productive institution with a total of $158(6.56 \%)$ documents. Average citation per document published in Arab countries was 13.25 and the $h$-index was 64. Tuberculosis (230; 9.55\%), malaria (223; 9.26\%), and hepatitis $(189 ; 7.8 \%)$ were the top three infectious diseases studied as according to the retrieved documents.

Conclusion: The present data reveals that some Arab countries contribute significantly to the field of infectious diseases. However, Arab countries need to work harder to bridge the gap in this field. Compared with non-Arab countries in the Middle East, research output from Arab countries was high, but more efforts are needed to enhance the quality of this output. Future research in the field should be encouraged and correctly directed.

Keywords: Bibliometric, Infectious diseases, Arab world, Web of science

\footnotetext{
*Correspondence: waleedsweileh@yahoo.com

'Department of Pharmacology and Toxicology, College of Medicine and

Health Sciences, An-Najah National University, Nablus, Palestine

Full list of author information is available at the end of the article
} 


\section{Multilingual abstracts}

Please see Additional file 1 for translation of the abstract into the six official working languages of the United Nations.

\section{Background}

According to the Arab Union League, there are 22 independent Arab states with more than 400 million inhabitants. Poverty, inadequate health services, political instability, and outbreaks of infectious diseases are common in many Arab countries [1-3]. For example, there was an outbreak of polio in Syria that made international agencies call for a ceasefire to accomplish a polio vaccination campaign [4]. Another example is the cholera outbreak in Baghdad after the second Gulf War [5]. In Saudi Arabia, several mortalities have been attributed to Middle East respiratory syndrome caused by the coronavirus infection [6-8]. Furthermore, pilgrimage and other religious seasons create a true challenge for Saudi Arabia to prevent and control outbreaks of infectious diseases during religious seasons [9-11]. Different types of infectious diseases are prevalent and have become a health burden for governments in many Arab countries. For example, according to the World Health Organization (WHO), in conservative communities that Arab countries fall into, HIV infections are rising at a faster rate, while the coverage of antiretroviral therapy is the lowest [12]. Furthermore, highly pathogenic and serious viral infections such as the avian flu virus, hepatitis $B$, and hepatitis $\mathrm{C}$ are important risks of morbidity and mortality, and pose real threats in some Arab countries such as Egypt [13-17]. Similarly, serious parasitic infections such as malaria, schistosomiasis, and trypanosomiasis constitute a major health, social, and economic challenge in Egypt, Sudan, Yemen, and other Arab countries [18-23]. Zoonotic infections, such as brucellosis and hydatid disease, are also present in several Arab countries and pose a continuous health challenge [24-28]. Furthermore, some infectious diseases such as nematode infections, filarial infections, schistosomiasis, fascioliasis, leprosy, and trachoma are endemic in some Arab countries and are being neglected [29]. In addition to the abovementioned challenges pertaining to infectious diseases, there is evidence that serious and common infectious agents in the Arab region, such as Mycobacterium tuberculosis, Staphylococcus aureus, and some gram-negative bacilli are developing multiple drug resistance which is a real future public health challenge at regional and global levels [30-38].

To meet future challenges regarding infectious diseases and limit the spread of multidrug resistant microorganisms in Arab countries, a better understanding of published studies in the field of infectious diseases is needed to have baseline data in this field so that future research can be encouraged and correctly directed. No bibliometric studies have addressed microbiological, or parasitological or viral or infectious diseases research activity in the Arab region. Most bibliometric studies in Arab countries have focused on biomedical research in general or on other medical areas $[39,40]$. Therefore, this study was carried out to investigate the quantity and quality of research activity in Arab countries in the field of infectious diseases. This bibliometric study assessed the past and current research activity in Arab countries in the field of infectious diseases, in order to draw future attention to research in this field.

\section{Methods}

The Web of Science (WoS) database was used to achieve the objective of this study. The WoS is a trustworthy, large, and powerful database for literature retrieval and analysis [41]. All Arab countries: Kingdom of Saudi Arabia (KSA), Egypt, Jordan, Lebanon, Qatar, Bahrain, Kuwait, Morocco, Tunisia, Syrian Arab Republic (SAR), United Arab Emirates (UAE), Iraq, Sudan, Yemen, Algeria, Comoros, Djibouti, Libya, Mauritania, Oman, Somalia, and Palestine, were used as the country keys, followed by "infectious diseases," which was used as the WoS category. Because WoS does not recognize Palestine as an independent state yet, search for documents about infectious diseases from Palestine was carried out using separate search keys in the database.

The search keys for the 21 Arab countries looked like this: $(\mathrm{CU}=$ (Jordan) $\mathrm{OR} C \mathrm{CU}=(\mathrm{Iraq}) \mathrm{OR} C \mathrm{CU}=($ Syria $)$ OR $\mathrm{CU}=$ (Saudi) OR $\mathrm{CU}=$ (Kuwait) $\mathrm{OR} \mathrm{CU}=$ (Egypt) $\mathrm{OR}$ $\mathrm{CU}=$ (Yemen) $\mathrm{OR} \mathrm{CU}=$ (Qatar) $\mathrm{OR} \mathrm{CU}=$ (Emirates) $\mathrm{OR}$ $\mathrm{CU}=($ Bahrain $)$ OR $\mathrm{CU}=($ Oman $)$ OR $\mathrm{CU}=($ Sudan $)$ OR $\mathrm{CU}=($ Tunisia $)$ OR $\mathrm{CU}=$ (Algeria) $\mathrm{OR} \mathrm{CU}=($ Lebanon $)$ OR $\quad \mathrm{CU}=($ Libya $) \quad \mathrm{OR} \quad \mathrm{CU}=($ Morocco $) \quad \mathrm{OR} \quad \mathrm{CU}=$ (Somalia) OR $\mathrm{CU}=($ Djibouti $)$ OR $\mathrm{CU}=($ Comoros $) \mathrm{OR}$ $\mathrm{CU}=($ Mauritania $)$ AND $\mathrm{WC}=$ (infectious diseases). The search keys for Palestine looked like this: $\mathrm{WC}=($ infectious diseases) AND $\mathrm{CI}=(($ Nablus $)$ OR (Jenin) OR (Ramallah) OR (Bethlehem) OR (Tulkarm) OR (Abu Dis) OR (Gaza)) AND CU = (Israel). The search for Palestinian research output in infectious diseases was based on the list of major Palestinian cities as a key research in addition to the name of Israel as a country since the WoS does not recognize Palestine as a state and considers all Palestinian publications to be affiliated with Israel.

The results from 21 Arab countries and those from Palestine were combined and the resultant data were analyzed. To increase the accuracy of the results, research was refined and limited to original research articles and review articles because they represent actual research activities, while other types of documents such as editorials, conference proceedings, and others were excluded. 
The timeframe for the results included all years up to 2012. The years 2013 and 2014 were excluded in order to enhance the accuracy of the results. If we included recent years, then we might not be able to retrieve the same number of documents if we re-do the analysis several months later because some journal issues are released and uploaded to WoS several months after publication online.

The WoS generates a count of the total number of original articles, total citations, and the value of the $h$-index. Scientific output was evaluated based on a methodology developed and used in other bibliometric studies [42-47]. The collected data were used to generate the following information: (a) total and trends of contributions in infectious diseases research up until the specified date of December 31, 2012; (b) Arab countries research productivity; (c) journals in which researchers from the Arab world were published; (d) $h$-index for retrieved publications from Arab countries; and finally (e) comparison of the results obtained from Arab countries with those obtained from non-Arab countries such as Turkey, Iran, and Israel.

\section{Statistical analysis}

Data from WoS were exported to a Microsoft Office ${ }^{\circ}$ Excel spreadsheet and then transferred to a Microsoft Word document. Results were converted to rank order using the standard competition ranking (SCR). We took into consideration the top 10 ranked publications in each item. If the measurements of bibliometric analysis had the same ranking number, then a gap was left in the ranking numbers which followed. The journal's impact factors (IF) were evaluated using the Journal Citation Report $^{\circ}$ (JCR; Web of Science) 2012 science edition, published by Thomson Reuters (New York, NY, USA).

\section{Results}

The total number of worldwide documents retrieved from WoS using the methodology stated and without specifying the name of any country was 227,188 . When the same methodology was applied using the list of Arab countries, 2,408 documents were retrieved. Therefore, research output from Arab countries in the field of infectious diseases represents $1.06 \%$ of worldwide research productivity. Table 1 lists the Arab countries and their standard competition rank (SCR) worldwide. In the same table, three non-Arab Middle Eastern countries are shown for comparative purposes.

The top 10 journals for publication of documents in the field of infectious diseases from Arab countries are shown in Table 2. Approximately $8.5 \%$ of documents from Arab countries in the field of infectious diseases were published in journals with an IF $>5$. In terms of
Table 1 List of Arab countries and three non-Arab countries in the Middle East and their Standard Competition Ranks (SCRs) in worldwide research productivity in the field of infectious diseases

\begin{tabular}{|c|c|}
\hline Arab Countries & Worldwide $S C R^{*}$ \\
\hline Egypt & 56 \\
\hline Kingdom of Saudi Arabia & 60 \\
\hline Tunisia & 68 \\
\hline Morocco & 81 \\
\hline Kuwait & 91 \\
\hline Lebanon & 93 \\
\hline Sudan & 86 \\
\hline Algeria & 103 \\
\hline United Arab Emirates & 105 \\
\hline Jordan & 130 \\
\hline Qatar & 136 \\
\hline Bahrain & 143 \\
\hline Oman & 157 \\
\hline Iraq & 163 \\
\hline Syria & 162 \\
\hline Yemen & 175 \\
\hline Libya & 170 \\
\hline Mauritania & 177 \\
\hline Palestine & $N / A^{*}$ \\
\hline Somalia & 210 \\
\hline Comoros & 213 \\
\hline Djibouti & 218 \\
\hline \multicolumn{2}{|l|}{ Non-Arab countries } \\
\hline Israel & 25 \\
\hline Turkey & 31 \\
\hline Iran & 46 \\
\hline
\end{tabular}

*Palestine is not recognized as an independent state in the WoS database, so rank could not be determine. Retrieval of documents from Palestine was explained in the methodology section.

worldwide documents, approximately $21.5 \%$ were published from journals with an IF $>5$.

The annual number of worldwide published documents was low up until 1970. A steady and obvious increase was seen after that. Growth of research in the field of infectious diseases worldwide and from Arab countries is shown in Figure 1. The figure presents the data from the 1960s to 2012. Data earlier than 1960 was excluded because the number of published documents before 1960 was relatively low. Both worldwide and Arab countries have shown a dramatic increase in research productivity in infectious diseases over time. The annual number of documents published in Arab countries indicated that research output in the field remained low until the mid-1980s and showed a great jump in the late 
Table 2 Top 10 journals in which documents in the field of infectious diseases were mostly published from Arab countries

\begin{tabular}{|c|c|c|c|}
\hline$S C R^{a}$ & Journal & Frequency $N=2408(\%)$ & $I F^{b}$ \\
\hline $1 \mathrm{st}$ & Medecine et Maladies Infectieuses & $202(8.39)$ & 0.753 \\
\hline 2nd & Bulletin de la Societe de Pathologie Exotique & $138(5.73)$ & NA \\
\hline 3nd & Journal of Infectious Diseases & $127(5.27)$ & 5.848 \\
\hline 4th & International Journal of Tuberculosis and Lung Disease & $115(4.78)$ & 2.610 \\
\hline 5 th & Journal of Infection in Developing Countries & $98(4.07)$ & 0.996 \\
\hline 6th & Emerging Infectious Diseases & $80(3.32)$ & 5.993 \\
\hline 7th & Journal of Infection & $77(3.20)$ & 4.073 \\
\hline 8th & Diagnostic Microbiology and Infectious Disease & $73(3.03)$ & 2.260 \\
\hline 9th & Infection and Immunity & $69(2.87)$ & 4.074 \\
\hline 10th & International Journal of Antimicrobial agents & $67(2.78)$ & 4.415 \\
\hline 10th & International Journal of Infectious Diseases & $67(2.78)$ & 2.357 \\
\hline
\end{tabular}

Abbreviations: SCR Standard Competition Ranking, NA not available, IF impact factor.

alf equal journals have the same ranking number, then a gap is left in the ranking numbers.

${ }^{\mathrm{b}}$ The impact factor was reported according to the Institute for Scientific Information (ISI) journal citation reports (JCR) 2012.

1990s. The first article published in the field of infectious diseases in Arab countries was co-authored by an Arab researcher from Egypt in 1928 [48]. The majority of documents retrieved from Arab countries were published in English (2,087; 86.66\%), followed by French (311; 12.92\%), and very few were published in Russian, Spanish, and German (10; 0.42\%).

When the retrieved documents were analyzed by country, Egypt $(464 ; 19.27 \%)$ had the highest research output, followed by the Kingdom of Saudi Arabia (437; $18.15 \%$ ) and Tunisia (365; 15.16\%) (see Table 3). All Arab countries, even those with low income and/or political instability such as Palestine, had some contribution to the field of infectious diseases research. The most research productive institute was Kuwait University followed by the American University in Beirut, with 158 (6.56\%) and 139 (5.78\%) documents, respectively. Researchers in Arab countries collaborated most with researchers from the USA (475; 19.73\%), France (257; 10.67\%), and England (162; 6.73\%).

Of the 2,408 documents considered for the $h$-index, 64 had been cited at least 64 times at the time of the data analysis. Analysis of citation revealed that the Arab country with the highest $h$-index was Egypt $(h$-index $=$

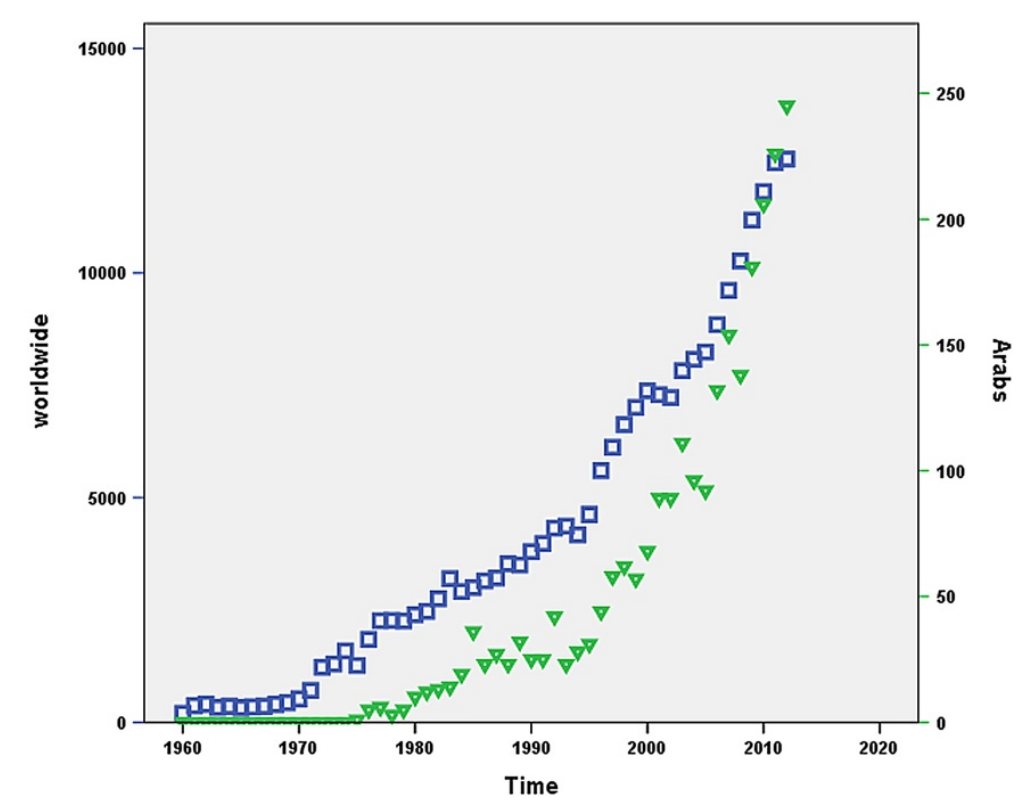

Figure 1 Growth of research productivity in the field of infectious diseases. The $\square$ line represents worldwide growth while the $\boldsymbol{\nabla}$ line represents growth of research in Arab countries. 
Table 3 Research productivity of Arab and three non-Arab countries in the field of infectious diseases, including the h-index and mean citation per document

\begin{tabular}{|c|c|c|c|}
\hline Arab country & Frequency $N=2408$ (\%) & h-index & Mean citation per document \\
\hline Egypt & $464(19.27)$ & 41 & 16.08 \\
\hline Kingdom of Saudi Arabia & $437(18.15)$ & 36 & 15.64 \\
\hline Tunisia & $365(15.16)$ & 25 & 8.89 \\
\hline Morocco & $216(8.97)$ & 22 & 9.96 \\
\hline Kuwait & $175(7.27)$ & 27 & 17.61 \\
\hline Lebanon & $173(7.18)$ & 24 & 14.14 \\
\hline Sudan & $165(6.85)$ & 28 & 16.28 \\
\hline Algeria & $134(5.57)$ & 16 & 8.06 \\
\hline United Arab Emirates & $128(5.32)$ & 27 & 19.98 \\
\hline Jordan & 79 (3.28) & 16 & 12.81 \\
\hline Qatar & $55(2.28)$ & 11 & 7.58 \\
\hline Bahrain & $44(1.83)$ & 11 & 9.82 \\
\hline Oman & $34(1.41)$ & 9 & 8.47 \\
\hline Iraq & $29(1.20)$ & 8 & 11.03 \\
\hline Syria & $29(1.20)$ & 10 & 8.21 \\
\hline Yemen & $23(0.96)$ & 6 & 5.62 \\
\hline Libya & $22(0.91)$ & 8 & 9.64 \\
\hline Mauritania & $19(0.79)$ & 8 & 10.00 \\
\hline Palestine & $11(0.46)$ & 4 & 4.91 \\
\hline Somalia & $6(0.25)$ & 4 & 12.33 \\
\hline Comoros & $6(0.25)$ & 4 & 5.17 \\
\hline Djibouti & $5(0.21)$ & 4 & 8.00 \\
\hline \multicolumn{4}{|c|}{ Non-Arab Countries versus 22 Arab Countries } \\
\hline "non-Arab countries" & 2,408 & 64 & 13.25 \\
\hline Israel & 2,095 & 93 & 24.11 \\
\hline Turkey & 1,461 & 53 & 12.77 \\
\hline Iran & 572 & 29 & 9.04 \\
\hline
\end{tabular}

41), while the country with the highest mean citation per document was the United Arab Emirates (20 citations per document). Compared with other non-Arab countries in the Middle East, the research output from Arab countries was higher than that from Israel, Turkey, and Iran. However, the quality of research output from Arab countries, measured as $h$-index, was less than that from Israel but higher than that from Turkey or Iran (see Table 3). The top infectious diseases studied as per the retrieved published documents were: tuberculosis (230; 9.55\%), malaria (223; 9.26\%), hepatitis (189; 7.8\%), HIV (186; 7.72\%), diarrhea/gastroenteritis (150; 6.23\%), meningitis $(115 ; 4.78 \%)$, leishmaniasis $(111 ; 4.6 \%)$, salmonella $(92 ; 3.82 \%)$, and influenza $(52 ; 2.16 \%)$.

\section{Discussion}

In this study, we assessed research productivity in the field of infectious diseases in Arab countries. Our results indicated that there is an obvious and promising rise in research activity in Arab countries in this field. However, none of the Arab countries ranked among the first 50 countries in terms of worldwide contribution to research output in this field. This was disappointing given that three non-Arab Middle Eastern countries-Israel, Iran, and Turkey-were ranked among the first top 50 countries. Among the Arab countries, Egypt and KSA occupied the top rank. Large populations and high national incomes are the most probable reasons for this. Compared with non-Arab countries in the Middle East, the number of published research documents in Arab countries was the highest. However, the quality of the published documents in Arab countries, as measured by the $h$-index and/or average citation per document, was lesser than that from Israel possibly because of the relatively low impact factor (IF) of journals in which the bulk of the documents from Arab countries were 
published. The citation is a key indicator of research quality [49]. The $h$-index was developed to overcome the main disadvantages of other bibliometric indicators, such as total number of papers or total number of citations. The $h$-index simultaneously measures the quality and quantity of scientific output, and is one of the most commonly used indicators of research quality. However, if the $h$-index is used to measure documents from different databases, then this can give different values. Therefore, each database has pros and cons when being measured by the $h$-index [50-52]. Criticisms have also been addressed to the use of the $h$-index as a marker of publication quality and citation. For example, the $h$ index does not consider the context of citations or the number of authors in the document, and gives equal values for book citation and research citations. Therefore, the $h$-index has a lesser predictive accuracy and precision than measuring using mean citations per paper, although this is controversial [53,54].

Infectious diseases have no borders and prevention; control and eradication of infectious diseases requires worldwide efforts. Arab countries have been the source of some fatal infectious diseases, and they should heavily participate and cooperate in research in order to combat them [55-58]. For example, the Middle East respiratory syndrome was initially diagnosed in KSA but reports of cases in distant parts of the world have been identified due to people traveling from KSA [59-62]. Several research documents about serious infectious agents such as the West Nile Virus have been published in the USA and Europe through cooperation with Arab institutions and investigators [63,64]. Arab countries should also cooperate in research regarding resistant cases of infectious agents particularly those pertaining to Mycobacterium tuberculosis. Emergence of resistant strains causing tuberculosis is a challenge for many developing countries [65]. Another important example of an infectious disease common in Arab countries that has been investigated through several cooperative research studies is leishmaniasis [66-68]. Cooperation in research becomes evident when we compare research interests of Arab investigators with those in other countries. Research collaboration improves the quality and quantity of research output, as well as the visibility of national health problems [69-72]. Furthermore, international collaboration in research helps in capacity building in developing countries and makes national problems of developing countries more observable [73]. Arab researchers need to take the lead and promote research projects in the field of infectious diseases as an important public health concern. Obstacles to do research such as inadequate funding, an unstable democratic atmosphere, and an unclear national policy toward health research are, unfortunately, prevalent in Arab countries. Everyone should participate in the war against infectious diseases including clerks and politicians who can help in the fight of infectious diseases such as HIV/AIDS [74,75]. Researchers, academics, and healthcare professionals should promote vaccinations against infectious diseases as well as public hygiene as a methods of early prevention [76,77]. Research output from a particular country is not only a point of prestige but also a reflection of the care of governments toward citizens and their individual health. Of course, the research activity and capacity of a particular country depends on several factors including the national income and the size of the population. However, in the case of infectious diseases, Arab countries, with a population of over 400 million and huge resources, must strive for excellence in research pertaining to infectious diseases. In addition, Arab countries need to invest in research in infectious diseases to limit the spread of microbial drug resistance that might be unique in different world regions. To achieve this, Arab countries must invest more in research activity in the field of infectious diseases.

Our study is the first to analyze the quantity and quality of research productivity in the field of infectious diseases in Arab countries. The database used for analysis, Web of Science (WoS), is one of the most trustworthy databases that allows for powerful citation analysis. It is well known that the most leading and influential journals in the field of medicine and health are indexed in WoS. However, articles published in non-WoS indexed journals were not included in the analysis. Despite this, the aim of this paper was to initiate discussion among professionals and academics pertaining to infectious diseases research activity in Arab countries rather than criticize or praise the research activity itself.

\section{Conclusion}

Our study showed that research in the field of infectious diseases is rising in some Arab countries such as Egypt and KSA, and that more efforts are required to bridge the gap with some of the other countries. Research collaboration between institutions in Arab countries with international researchers and institutions in the field of infectious diseases should be sought. Governmental funding and support for infectious diseases research is also recommended.

\section{Additional files}

Additional file 1: Multilingual abstracts in the six official working

languages of the United Nations.

\section{Abbreviations}

WoS: Web of Science; KSA: Kingdom of Saudi Arabia; USA: United States of America; JCR: Journal citation report; SCR: Standard competition ranking; IFs: Impact factors. 


\section{Competing interests}

The authors declare that they have no competing interests.

\section{Authors' contributions}

All authors were involved in the drafting of the article and all authors approved the final version to be submitted for publication. All authors added a significant intellectual value to the manuscript.

\section{Acknowledgements}

The authors would like to express gratitude to the An-Najah University for help in conducting this study.

\section{Author details}

'Department of Pharmacology and Toxicology, College of Medicine and Health Sciences, An-Najah National University, Nablus, Palestine. ${ }^{2}$ Department of Clinical and Community Pharmacy, College of Medicine and Health Sciences, An-Najah National University, Nablus, Palestine. ${ }^{3}$ Department of Microbiology and Immunology, College of Medicine and Health Sciences, An-Najah National University, Nablus, Palestine. ${ }^{4}$ Department of Biochemistry and Genetics, College of Medicine and Health Sciences, An-Najah National University, Nablus, Palestine.

\section{Received: 27 August 2014 Accepted: 22 December 2014}

Published: 2 February 2015

\section{References}

1. Batniji R, Khatib L, Cammett M, Sweet J, Basu S, Jamal A, et al. Governance and health in the Arab world. Lancet. 2014;383:343-55.

2. Jabbour S, Giacaman R, Yamout R, Khawaja M. Public health in the Arab World: Cambridge University Press; 2012.

3. Mokdad AH, Jaber S, Aziz MI, AlBuhairan F, AlGhaithi A, AlHamad NM, et al. The state of health in the Arab world, 1990-2010: an analysis of the burden of diseases, injuries, and risk factors. Lancet. 2014;383:309-20.

4. Arie S. Polio outbreak leads to calls for a "vaccination ceasefire" in Syria. BMJ. 2013:347:f6682.

5. Khwaif J, Hayyawi A, Yousif T. Cholera outbreak in Baghdad in 2007: an epidemiological study. East Mediterr Health J. 2010;16:584-9.

6. Memish ZA, Zumla Al, Al-Hakeem RF, Al-Rabeeah AA, Stephens GM. Family cluster of Middle East respiratory syndrome coronavirus infections. N Engl J Med. 2013;368:2487-94.

7. Assiri A, Al-Tawfiq JA, Al-Rabeeah AA, Al-Rabiah FA, Al-Hajjar S, Al-Barrak A, et al. Epidemiological, demographic, and clinical characteristics of 47 cases of Middle East respiratory syndrome coronavirus disease from Saudi Arabia: a descriptive study. Lancet Infect Dis. 2013;13:752-61.

8. Al-Ahdal MN, Al-Qahtani AA, Rubino S. Coronavirus respiratory illness in Saudi Arabia. J Infect Dev Ctries. 2012;6:692-4.

9. Shibl A, Senok A, Memish Z. Infectious diseases in the Arabian Peninsula and Egypt. Clin Microbiol Infect. 2012;18:1068-80.

10. Al-Tawfiq JA, Memish ZA. The Hajj: updated health hazards and current recommendations for 2012. Euro Surveill. 2012;17:6-10.

11. Mandourah Y, Al-Radi A, Ocheltree AH, Ocheltree SR, Fowler RA. Clinical and temporal patterns of severe pneumonia causing critical illness during Hajj. BMC Infect Dis. 2012;12:117.

12. Alwan A. Responding to priority health challenges in the Arab world. Lancet. 2014:383:284-6.

13. Aamir U, Wernery U, Iyushina N, Webster R. Characterization of avian H9N2 influenza viruses from United Arab Emirates 2000 to 2003. Virology. 2007;361:45-55.

14. Abdelwhab EM, Hafez HM. An overview of the epidemic of highly pathogenic H5N1 avian influenza virus in Egypt: epidemiology and control challenges. Epidemiol Infect. 2011;139:647-57.

15. Gasim GI, Murad IA, Adam I. Hepatitis B and C virus infections among pregnant women in Arab and African countries. J Infect Dev Ctries. 2013;7:566-78.

16. Mohamoud YA, Mumtaz GR, Riome S, Miller D, Abu-Raddad LJ. The epidemiology of hepatitis C virus in Egypt: a systematic review and data synthesis. BMC Infect Dis. 2013;13:288.

17. Daw MA, Dau AA. Hepatitis C virus in Arab world: a state of concern. ScientificWorldJournal. 2012;2012:719494.
18. Adam I, Elhassan EM, Haggaz AD, Ali AAA, Adam GK. A perspective of the epidemiology of malaria and anaemia and their impact on maternal and perinatal outcomes in Sudan. J Infect Dev Ctries. 2011;5:83-7.

19. Awofeso N. Towards global Guinea worm eradication in 2015: the experience of South Sudan. Int J Infect Dis. 2013;17:E577-82.

20. Hassan OA, Ahlm C, Sang R, Evander M. The 2007 Rift Valley Fever Outbreak in Sudan. PLoS Negl Trop Dis. 2011;5:e1229.

21. Ruiz-Postigo JA, Franco JR, Lado M, Simarro PP. Human African Trypanosomiasis in South Sudan: How Can We Prevent a New Epidemic? PLoS Negl Trop Dis. 2012;6:e1541.

22. Ramsay A, Al-Agbhari N, Scherchand J, Al-Sonboli N, Almotawa A, Gammo $M$, et al. Direct patient costs associated with tuberculosis diagnosis in Yemen and Nepal. Int J Tuberc Lung Dis. 2010;14:165-70.

23. Sady H, Al-Mekhlafi HM, Mahdy MAK, Lim YAL, Mahmud R, Surin J. Prevalence and Associated Factors of Schistosomiasis among Children in Yemen: Implications for an Effective Control Programme. PLOS Negl Trop Dis. 2013;7:e2377.

24. Balkhy HH, Memish ZA. Rift Valley fever: an uninvited zoonosis in the Arabian peninsula. Int J Antimicrob Agents. 2003;21:153-7.

25. Nemenqani D, Yaqoob N, Khoja H. Breast Brucellosis in Taif, Saudi Arabia: cluster of six cases with emphasis on FNA evaluation. J Infect Dev Ctries. 2009;3:255-9.

26. Al-Majali AM, Shorman M. Childhood brucellosis in Jordan: prevalence and analysis of risk factors. Int J Infect Dis. 2009;13:196-200.

27. Samaha H, Al-Rowaily M, Khoudair RM, Ashour HM. Multicenter Study of Brucellosis in Egypt. Emerg Infect Dis. 2008;14:1916-8.

28. Sadjjadi SM. Present situation of echinococcosis in the Middle East and Arabic North Africa. Parasitol Int. 2006;55:S197-202.

29. Hotez PJ, Savioli L, Fenwick A. Neglected tropical diseases of the Middle East and North Africa: review of their prevalence, distribution, and opportunities for control. PLoS Negl Trop Dis. 2012;6:e1475.

30. Aldeyab MA, Kearney MP, Scott MG, Aldiab MA, Alahmadi YM, Elhajji FWD, et al. An evaluation of the impact of antibiotic stewardship on reducing the use of high-risk antibiotics and its effect on the incidence of Clostridium difficile infection in hospital settings. J Antimicrob Chemother. 2012;67:2988-96.

31. Hamzeh AR, Al Najjar M, Mahfoud M. Prevalence of antibiotic resistance among Acinetobacter baumannii isolates from Aleppo, Syria. Am J Infect Control. 2012:40:776-7.

32. Bakour S, Touati A, Sahli F, Ameur AA, Haouchine D, Rolain JM. Antibiotic resistance determinants of multidrug-resistant Acinetobacter baumannii clinical isolates in Algeria. Diagn Microbiol Infect Dis. 2013;76:529-31.

33. Finley RL, Collignon P, Larsson DGJ, McEwen SA, Li XZ, Gaze WH, et al. The Scourge of Antibiotic Resistance: The Important Role of the Environment. Clin Infect Dis. 2013;57:704-10.

34. Garbati MA, Bin Abdulhak A, Baba K, Sakkijha H. Infection due to colistin-resistant Enterobacteriacae in critically-ill patients. J Infect Dev Ctries. 2013;7:713-9.

35. Osman KM, Marouf SH, Alatfeehy N. Antimicrobial Resistance and Virulence-Associated Genes of Salmonella enterica Subsp enterica Serotypes Muenster, Florian, Omuna, and Noya Strains Isolated from Clinically Diarrheic Humans in Egypt. Microb Drug Resist. 2013;19:370-7.

36. Zumla A, Abubakar I, Raviglione M, Hoelscher M, Ditiu L, McHugh TD, et al. Drug-Resistant Tuberculosis-Current Dilemmas, Unanswered Questions, Challenges, and Priority Needs. J Infect Dis. 2012;205:S228-40.

37. Menif K, Bouziri A, Khaldi A, Hamdi A, Belhadj S, Borgi A, et al. Communityassociated methicillin-resistant Staphylococcus aureus infections in a pediatric intensive care unit. J Infect Dev Ctries. 2011:5:587-91.

38. Buzaid N, Elzouki AN, Taher I, Ghenghesh KS. Methicillin-resistant Staphylococcus aureus (MRSA) in a tertiary surgical and trauma hospital in Benghazi, Libya. J Infect Dev Ctries. 2011;5:723-6.

39. Bissar-Tadmouri N, Tadmouri GO. Bibliometric analyses of biomedical research outputs in Lebanon and the United Arab Emirates (1988-2007). Saudi Med J. 2009;30:130-9.

40. Sweileh WM, Zyoud SH, Al-Jabi SW, Sawalha AF. Assessing urology and nephrology research activity in Arab countries using ISI web of science bibliometric database. BMC Res Notes. 2014;7:258.

41. Thomson R. Web of Knowledge. 2013 [cited 2013 December 11]; Available from: http://wokinfo.com/media/pdf/SSR1103443WoK5-2_web3.pdf.

42. Sweileh WM, AI-Jabi SW, Zyoud SH, Sawalha AF. Bronchial asthma and chronic obstructive pulmonary disease: research activity in Arab countries. Multidiscip Respir Med. 2014;9:38. 
43. Sweileh WM, Al-Jabi SW, Zyoud SH, Sawalha AF, Ghanim MA. Osteoporosis is a neglected health priority in Arab World: a comparative bibliometric analysis. Springerplus. 2014;3:427.

44. Sweileh WM, Zyoud SE, AI-Jabi SW, Sawalha AF. Substance use disorders in Arab countries: research activity and bibliometric analysis. Subst Abuse Treat Prev Policy. 2014;9:33.

45. Sweileh WM, Zyoud SH, Al-Jabi SW, Sawalha AF. Quantity and quality of obesity-related research in Arab countries: assessment and comparative analysis. Health Res Policy Syst. 2014;12:33.

46. Zyoud SH, Al-Jabi SW, Sweileh WM. Worldwide research productivity in the field of electronic cigarette: a bibliometric analysis. BMC Public Health. 2014;14:667.

47. Sweileh W, Al-Jabi S, Sawalha A. Zyoud Se: Bibliometric analysis of nutrition and dietetics research activity in Arab countries using ISI Web of Science database. SpringerPlus. 2014;3:718.

48. Compton A. Sensitization and immunization with bacteriophage in experimental plague. J Infect Dis. 1928:43:448-57.

49. Vinkler $\mathrm{P}$. Eminence of scientists in the light of the h-index and other scientometric indicators. J Inform Sci. 2007:33:481-91.

50. Jacsó P. The pros and cons of computing the h-index using Web of Science. Online Inform Rev. 2008:32:673-88.

51. Jacsó P. The pros and cons of computing the h-index using Scopus. Online Inform Rev. 2008:32:524-35.

52. Jacsó P. The pros and cons of computing the h-index using Google Scholar. Online Inform Rev. 2008:32:437-52.

53. Lehmann $\mathrm{S}$, Jackson AD, Lautrup BE. Measures for measures. Nature. 2006:444:1003-4.

54. Hirsch JE. Does the $\mathrm{h}$ index have predictive power? Proc Natl Acad Sci U S A. $2007 ; 104: 19193-8$

55. Leventhal A, Ramlawi A, Belbiesi A, Balicer RD. Regional collaboration in the Middle East to deal with H5N1 avian flu. BMJ. 2006;333:856-8.

56. Saad MD, Lu'ay SA, Gamal-Eldein MA, Fouda MK, Khalil FM, Yingst SL, et al. Possible avian influenza (H5N1) from migratory bird, Egypt. Emerg Infect Dis. 2007:13:1120-1.

57. Meleigy M. Egypt battles with avian influenza. Lancet. 2007;370:553-4.

58. Aly M, Arafa A, Hassan M. Epidemiological findings of outbreaks of disease caused by highly pathogenic $\mathrm{H} 5 \mathrm{~N} 1$ avian influenza virus in poultry in Egypt during 2006. Avian Dis. 2008:52:269-77.

59. Lu L, Liu Q, Du L, Jiang S. Middle East respiratory syndrome coronavirus (MERS-CoV): challenges in identifying its source and controlling its spread. Microbes Infect. 2013;15:625-9.

60. de Groot RJ, Baker SC, Baric RS, Brown CS, Drosten C, Enjuanes L, et al. Middle East respiratory syndrome coronavirus (MERS-CoV): announcement of the Coronavirus Study Group. J Virol. 2013;87:7790-2.

61. Ithete NL, Stoffberg S, Corman VM, Cottontail VM, Richards LR, Schoeman $M C$, et al. Close relative of human Middle East respiratory syndrome coronavirus in bat, South Africa. Emerg Infect Dis. 2013;19:1697-9.

62. Bermingham A, Chand M, Brown C, Aarons E, Tong C, Langrish C, et al. Severe respiratory illness caused by a novel coronavirus, in a patient transferred to the United Kingdom from the Middle East, September 2012. Euro Surveill. 2012;17:20290

63. Bakonyi T, Ivanics T, Erdelyi K, Ursu K, Ferenczi E, Weissenbock H, et al. Lineage 1 and 2 strains of encephalitic West Nile virus, central Europe. Emerg Infect Dis. 2006;12:618-23

64. Andreadis TG, Anderson JF, Vossbrinck CR, Main AJ. Epidemiology of West Nile virus in Connecticut: A five-year analysis of mosquito data 1999-2003. Vector Borne Zoonotic Dis. 2004:4:360-78.

65. Shah NS, Wright A, Bai GH, Barrera L, Boulahbal F, Martin-Casabona N, et al Worldwide emergence of extensively drug-resistant tuberculosis. Emerg Infect Dis. 2007:13:380-7.

66. Bucheton B, Kheir MM, El-Safi SH, Hammad A, Mergani A, Mary C, et al. The interplay between environmental and host factors during an outbreak of visceral leishmaniasis in eastern Sudan. Microbes Infect. 2002;4:1449-57.

67. Dereure J, El-Safi SH, Bucheton B, Boni M, Kheir MM, Davoust B, et al. Viscera leishmaniasis in eastern Sudan: parasite identification in humans and dogs; host-parasite relationships. Microbes Infect. 2003:5:1103-8.

68. Reithinger R, Dujardin JC, Louzir H, Pirmez C, Alexander B, Brooker S. Cutaneous leishmaniasis. Lancet Infect Dis. 2007:7:581-96.

69. Bordons M, Gomez I, Fernandez MT, Zulueta MA, Mendez A. Local, domestic and international scientific collaboration in biomedical research. Scientometrics. 1996:37:279-95.
70. Bozeman B, Corley E. Scientists' collaboration strategies: implications for scientific and technical human capital. Res Policy. 2004;33:599-616.

71. Wagner CS. Six case studies of international collaboration in science. Scientometrics. 2005:62:3-26.

72. Basu A, Kumar BSV. International collaboration in Indian scientific papers Scientometrics. 2000:48:381-402.

73. Nauen CE. Ten years of international scientific cooperation in fisheries, aquaculture and coastal zones: some preliminary lessons. Environ Dev Sustain. 2008;10:605-22.

74. Hermez J, Petrak J, Karkouri M, Riedner G. A review of HIV testing and counseling policies and practices in the Eastern Mediterranean Region. AIDS. 2010;24:S25-32.

75. Alkaiyat A, Weiss MG. HIV in the Middle East and North Africa: priority, culture, and control. Int J Public Health. 2013;58:927-37.

76. Moulin AM. The social and political issues of vaccinations. Med Mal Infect. 2003;33:564-9.

77. Jumaa PA. Hand hygiene: simple and complex. Int J Infect Dis. 2005;9:3-14

doi:10.1186/2049-9957-4-2

Cite this article as: Sweileh et al:: Assessment of research productivity of Arab countries in the field of infectious diseases using Web of Science database. Infectious Diseases of Poverty 2015 4:2.

\section{Submit your next manuscript to BioMed Central and take full advantage of:}

- Convenient online submission

- Thorough peer review

- No space constraints or color figure charges

- Immediate publication on acceptance

- Inclusion in PubMed, CAS, Scopus and Google Scholar

- Research which is freely available for redistribution

Submit your manuscript at www.biomedcentral.com/submit 